\title{
Hubungan Penggunaan Rokok Elektrik dengan Status Kebersihan Gigi dan Mulut pada Komunitas Manado Vapers
}

\author{
${ }^{1}$ Junior N. W. Oroh \\ ${ }^{2}$ Pieter L. Suling \\ ${ }^{3}$ Kustina Zuliari \\ ${ }^{1}$ Program Studi Pendidikan Dokter Gigi Fakultas Kedokteran \\ ${ }^{2}$ Bagian Ilmu Penyakit Kulit dan Kelamin Fakultas Kedokteran \\ ${ }^{3}$ Bagian Periodonsia Program Studi Pendidikan Dokter Gigi Fakultas Kedokteran \\ Universitas Sam Ratulangi Manado \\ Email: juniororoh18@gmail.com
}

\begin{abstract}
E-cigarette or electronic cigarette is one of the methods of nicotine replacement therapy (NRT) designed to replace nicotine intake without tobacco. Initially, it was thought that the e-cigarette was a much safer alternative than the conventional cigarette. In fact, this ecigarette can still pose dangerous side-effects to the users' general health, including oral and dental health. This study was aimed to identify the relationship between the frequency of ecigarette use and dental and oral health status in a community called Manado vapers in Manado. Samples were 32 e-cigarette users obtained by using total sampling of the community that fulfilled the inclusion criteria of this study. This was a descriptive analytical study with a cross-sectional design. Data were obtained by using questionnaire and OHI-S index. The Pearson's correlation test performed on the relationship between the frequency of e-cigarette and oral health as well as dental health obtained a $P$ value of 0.556. Conclusion: There was no significant relationship between frequency of e-cigarette use and oral and dental health among Manado vapers community in Manado.
\end{abstract}

Keywords: smoking, e-cigarette, oral and dental health status

\begin{abstract}
Abstrak: Rokok elektrik merupakan salah satu nicotine replacement therapy (NRT) yang dirancang untuk memberikan asupan nikotin tanpa pembakaran tembakau. Cara ini dikatakan lebih aman daripada rokok konvensional, namun ternyata tetap terdapat dampak bagi kesehatan tubuh, termasuk juga kesehatan gigi dan mulut. Penelitian ini bertujuan untuk mengetahui hubungan frekuensi penggunaan rokok elektrik dengan status kebersihan gigi dan mulut pada komunitas Manado vapers di kota Manado. Sampel penelitian ini yaitu 32 responden yang merupakan anggota Manado vapers pengguna rokok elektrik diambil menggunakan metode total sampling. Jenis penelitian ialah deskriptif analitik dengan desain potong lintang. Data diperoleh dengan menggunakan kuesioner dan indeks OHI-S. Hasil uji korelasi Pearson terhadap hubungan antara frekuensi penggunaan rokok elektrik dengan status kebersihan gigi dan mulut mendapatkan nilai $P=0,556$. Simpulan: Tidak terdapat hubungan bermakna antara frekuensi penggunaan rokok elektrik dengan status kebersihan gigi dan mulut pada komunitas Manado vapers di kota Manado.
\end{abstract}

Kata kunci: merokok, rokok elektrik, status kesehatan gigi dan mulut

Merokok merupakan kebiasaan yang memiliki daya rusak cukup besar terhadap kesehatan. Menurut World Health Organization (WHO), lingkungan asap rokok merupakan penyebab berbagai penyakit, baik bagi perokok aktif maupun pasif. Merokok tidak hanya menimbulkan efek secara sistemik, tetapi juga dapat menye- 
babkan timbulnya kondisi patologik di rongga mulut. Gigi dan jaringan lunak rongga mulut juga merupakan bagian yang dapat mengalami kerusakan akibat rokok. ${ }^{1}$ Menurut Riset Kesehatan Dasar (Riskesdas) tahun 2013, angka perokok di Indonesia mencapai 29,3\%. Di provinsi Sulawesi Utara sendiri angka perokok mencapai $30,5 \%$, dengan jumlah batang rokok yang dihisap setiap harinya yaitu sekitar 13,2 batang (sekitar 1 bungkus rokok per hari). ${ }^{2}$

Epidemi penyakit akibat rokok ini merupakan salah satu ancaman kesehatan terbesar di dunia saat ini. Telah diperkirakan bahwa lebih dari 1,3 miliar perokok di seluruh dunia, sekitar setengah dari penggunanya saat ini akan mati akibat penyakit yang berhubungan dengan rokok. Laporan WHO tahun 2009 berjudul The Global Tobacco Epidemic menyebutkan bahwa diperkirakan penggunaan rokok tembakau menyebabkan kematian lebih dari 5 juta orang di seluruh dunia setiap tahun dan umumnya terjadi di negaranegara berkembang dengan pendapatan perkapita rendah hingga sedang. ${ }^{3}$

Pemerintah di seluruh dunia melakukan berbagai upaya untuk menekan epidemi yang diakibatkan oleh rokok, salah satunya yaitu dengan menggunakan Nicotine Replacement Therapy (terapi pengganti nikotin, NRT). Terapi ini bertujuan untuk menggantikan asupan nikotin yang sebelumnya diperoleh dari rokok. Metode ini biasanya menggunakan suatu media untuk memberikan nikotin yang dibutuhkan perokok tanpa melalui pembakaran tembakau. ${ }^{3,4}$ Terdapat beberapa jenis NRT namun jenis yang sedang menjadi tren dalam beberapa tahun terakhir ini yaitu rokok elektrik. Rokok elektrik atau rokok elektronik merupakan salah satu NRT yang menggunakan listrik dari tenaga baterai untuk memberikan nikotin dalam bentuk uap dengan tetap memberikan sensasi merokok kepada penggunanya. ${ }^{5}$

Rokok elektrik atau e-cigarette pada awalnya dikatakan aman bagi kesehatan karena larutan nikotin yang terdapat pada rokok elektrik hanya terdiri dari campuran air, propilen glikol, zat penambah rasa, aroma tembakau, serta senyawa-senyawa lain yang tidak mengandung tar, tembakau atau zat-zat toksik lain yang umum terdapat pada rokok tembakau. Penelitian analitik yang didanai produsen e-cigarette oleh Laugesen et al. ${ }^{6}$ mengatakan bahwa $e$ cigarette lebih aman daripada rokok tembakau karena kadar nikotin yang lebih rendah dan tanpa pembakaran tembakau. Berdasarkan data-data tersebut e-cigarette dengan gencar dipasarkan ke seluruh dunia sebagai alternatif rokok tembakau yang seolah-olah lebih aman bagi kesehatan dan tidak melanggar peraturan bebas rokok. ${ }^{5}$ Namun ternyata setelah dilakukan penelitian lebih lanjut tentang rokok elektrik yang diprakarsai oleh FDA di Amerika pada tahun 2009 dilaporkan bahwa rokok elektrik mengandung tobacco specific nitrosamines (TSNA) yang bersifat toksik dan diethylene glycol (DEG) yang dikenal sebagai karsinogen. Banyak penelitian mengenai rokok elektrik, telah dilakukan namun belum ada kesepakatan pendapat mengenai rokok elektrik dan dampaknya bagi kesehatan karena tidak tersedianya data objektif yang cukup untuk dijadikan sebagai alasan yang kuat. ${ }^{5}$

\section{METODE PENELITIAN}

Jenis penelitian ini ialah deskriptif analitik dengan desain potong lintang. Penelitian dilaksanakan di café Whatsup pada bulan Mei tahun 2018. Populasi penelitian ialah seluruh anggota komunitas Manadovapers yang aktif mengikuti kegiatan yaitu sebanyak 60 orang.

Pengambilan sampel menggunakan metode total sampling yang memenuhi kriteria inklusi (anggota komunitas Manado vapers, pengguna rokok elektrik yang tidak menggunakan rokok konvensional, berusia lebih dari 18 tahun dengan keadaan sehat jasmani, bersedia menjadi responden penelitian, menyikat gigi minimal 2 kali sehari, anggota komunitas yang menghadiri penelitian) dengan jumlah sampel sebanyak 32 responden.

Pengumpulan data dilakukan dengan mengisi kuesioner data demografi dan pengukuran status kebersihan gigi dan mulut menggunakan indeks OHI-S. 
Data penelitian ini dianalisis dengan menggunakan uji normalitas KolmogorovSmirnov dan dilanjutkan dengan uji korelasi sederhana Pearson untuk menganalisis hubungan antara penggunaan rokok elektrik dengan status kebersihan gigi dan mulut pada komunitas Manado vapers. Bila nilai $P>0,05$ berarti tidak terdapat hubungan bermakna antara kedua variabel. Hasil penelitian disajikan dalam bentuk tabel kemudian dideskripsikan berdasarkan distribusi frekuensi dan hasil analisis data.

\section{HASIL PENELITIAN}

Tabel 1 menunjukkan karakteristik responden berdasarkan jenis kelamin dengan jumlah responden laki-laki $(71,875 \%)$ lebih banyak daripada perempuan $(28,125 \%)$.

Tabel 1. Karakteristik responden berdasarkan jenis kelamin

\begin{tabular}{ccc}
\hline $\begin{array}{c}\text { Jenis } \\
\text { kelamin }\end{array}$ & $\begin{array}{c}\text { Frekuensi } \\
(\mathbf{n})\end{array}$ & $\begin{array}{c}\text { Persentase } \\
(\boldsymbol{\%})\end{array}$ \\
\hline Laki-laki & 23 & 71,875 \\
Perempuan & 9 & 28,125 \\
Total & 32 & 100 \\
\hline
\end{tabular}

Tabel 2 menunjukkan bahwa berdasarkan usia responden di kelompok usia 23-27 tahun yang terbanyak yaitu 16 orang (50\%), disusul oleh responden di kelompok usia 18-22 tahun yaitu 15 orang $(46,875 \%)$ dan responden di kelompok usia 27-30 tahun yaitu 1 orang $(3,125 \%)$.

Tabel 2. Karakteristik responden berdasarkan usia

\begin{tabular}{ccc}
\hline $\begin{array}{c}\text { Usia } \\
\text { tahun) }\end{array}$ & $\begin{array}{c}\text { Frekuensi } \\
(\mathbf{n})\end{array}$ & Persentase (\%) \\
\hline $18-22$ & 15 & 46,875 \\
$23-27$ & 16 & 50 \\
$27-30$ & 1 & 3,125 \\
Total & 32 & 100 \\
\hline
\end{tabular}

Tabel 3 menampilkan bahwa sebagian responden mempunyai riwayat penggunaan rokok konvensional $(68,75 \%)$.

Tabel 4 menunjukkan bahwa berdasarkan frekuensi penggunaan rokok elektrik jumlah pengguna sedang dan sangat berat sama banyak (masing-masing 10 responden) sedangkan jumlah pengguna ringan dan berat sama banyak (masing-masing 6 responden).

Tabel 3. Karakteristik responden berdasarkan riwayat penggunaan rokok konvensional

\begin{tabular}{ccc}
\hline $\begin{array}{c}\text { Riwayat peng- } \\
\text { gunaan rokok } \\
\text { konvensional }\end{array}$ & $\begin{array}{c}\text { Frekuensi } \\
(\mathbf{n})\end{array}$ & $\begin{array}{c}\text { Persentase } \\
(\boldsymbol{\%})\end{array}$ \\
\hline Tidak pernah & 10 & 31,25 \\
Pernah & 22 & 68,75 \\
Total & 32 & 100 \\
\hline
\end{tabular}

Tabel 4. Karakteristik responden berdasarkan frekuensi penggunaan rokok elektrik

\begin{tabular}{ccc}
\hline $\begin{array}{c}\text { Frekuensi } \\
\text { penggunaan } \\
\text { rokok elektrik }\end{array}$ & $\begin{array}{c}\text { Frekuensi } \\
(\mathbf{n})\end{array}$ & $\begin{array}{c}\text { Persentase } \\
(\boldsymbol{\%})\end{array}$ \\
\hline Ringan & 6 & 18,75 \\
Sedang & 10 & 31,25 \\
Berat & 6 & 18,75 \\
Sangat berat & 10 & 31,25 \\
Total & 32 & 100 \\
\hline
\end{tabular}

Tabel 5 memperlihatkan bahwa sebagian besar responden $(59,375 \%)$ memiliki status OHI-S sedang.

Tabel 5. Karakteristik responden berdasarkan status kebersihan gigi dan mulut

\begin{tabular}{ccc}
\hline Status OHI-S & $\begin{array}{c}\text { Frekuensi } \\
(\mathbf{n})\end{array}$ & $\begin{array}{c}\text { Persentase } \\
(\boldsymbol{\%})\end{array}$ \\
\hline Baik & 6 & 18,75 \\
Sedang & 19 & 59,375 \\
Buruk & 7 & 21,875 \\
Total & 32 & 100 \\
\hline
\end{tabular}

Tabel 6 memperlihatkan hasil uji statistik menggunakan uji korelasi sederhana Pearson terhadap hubungan antara status OHI-S dan frekuensi penggunaan rokok elektrik yang mendapatkan nilai $P=$ 0,556 . Hal ini menunjukkan bahwa tidak terdapat hubungan bermakna antara keduanya. 
Tabel 6. Hasil uji statistik menggunakan uji korelasi sederhana Pearson

\begin{tabular}{cccccccccc}
\hline $\begin{array}{c}\text { Status } \\
\text { Frekuensi } \\
\text { penggunaan } \\
\text { rokok elektrik }\end{array}$ & Baik & Sedang & Buruk & Total & $\boldsymbol{P}$ \\
\hline Ringan & 2 & 6,25 & 2 & 6,25 & 2 & 6,25 & 6 & 18,75 & \\
Sedang & 0 & 0 & 9 & 28,12 & 1 & 3,12 & 10 & 31,25 & \\
Berat & 2 & 6,25 & 4 & 12,5 & 0 & 0 & 6 & 18,75 & 0,556 \\
Sangat berat & 2 & 6,25 & 4 & 12,5 & 4 & 12,5 & 10 & 31,25 & \\
Total & 6 & 18,75 & 19 & 59,37 & 7 & 21,87 & 32 & 100 & \\
\hline
\end{tabular}

\section{BAHASAN}

Rokok elektrik pada awalnya dipromosikan sebagai salah satu dari metode NRT yang berfungsi sebagai alat bantu untuk berhenti merokok dan juga merupakan alternatif bagi pecandu nikotin yang masih menggunakan rokok konvensional.

Banyak pengguna rokok konvensional yang beralih menggunakan rokok elektrik karena beranggapan bahwa rokok tersebut jauh lebih aman dari rokok konvensional. Namun, masih banyak pertanyaan yang belum terjawab mengenai tingkat keamanan, efek terhadap penggunaan jangka panjang, serta dampak pada kesehatan yang disebabkan oleh penggunaan rokok elektrik. Hal ini disebabkan masih kurangnya penelitian mengenai dampak rokok elektrik bagi kesehatan di Indonesia, khususnya dalam bidang kesehatan gigi dan mulut.

Berdasarkan hasil penelitian dapat dilihat bahwa sebagian besar pengguna rokok elektrik yang diteliti merupakan bekas pengguna rokok konvensional yaitu sebanyak 22 responden $(68,75 \%)$ sedangkan pengguna rokok elektrik yang tidak pernah menggunakan rokok konvensional berjumlah 10 responden $(31,25 \%)$. Hal ini sejalan dengan penelitian yang dilakukan oleh Damayanti ${ }^{3}$ yang melaporkan bahwa dari 32 responden, $29(93,6 \%)$ di antaranya mempunyai riwayat merokok konvensional dan sebagian besar mempunyai alasan menggunakan rokok elektrik sebagai alternatif untuk berhenti merokok. Hal ini juga selaras dengan penelitian yang dilakukan oleh Etter dan Bullen ${ }^{6}$ mengenai studi longitudinal tentang pengguna rokok elektrik dimana dari total 477 responden, 345 responden $(72 \%)$ merupakan bekas pengguna rokok konvensional. Pada penelitian yang dilakukan oleh Dawkins et al. ${ }^{7}$ didapatkan dugaan tentang motivasi seseorang untuk menggunakan rokok elektrik yaitu sebagai upaya untuk berhenti merokok dan juga menemukan bahwa motivasi untuk menggunakan rokok elektrik cukup beragam. Selain digunakan sebagai alternatif untuk berhenti merokok pengguna rokok elektrik juga menyukai produk ini dikarenakan variasi rasa yang ditawarkan di liquid, lebih banyak variasi dibandingkan rokok konvensional sehingga para pengguna tidak merasa bosan. ${ }^{6,7}$

Berdasarkan hasil penelitian setelah dibuat tabel silang antara frekuensi penggunaan rokok elektrik dengan status kebersihan gigi dan mulut responden didapatkan bahwa responden dengan penggunaan rokok elektrik sedang dan status kebersihan mulut kategori sedang memiliki persentase tertinggi yaitu sebanyak 9 responden $(28,125 \%)$, sedangkan persentase terendah yaitu responden dengan frekuensi penggunaan sedang dan status kebersihan gigi mulut buruk yaitu sebanyak 1 responden $(3,125 \%)$. Hasil uji statistik menggunakan uji korelasi Pearson menunjukkan tidak terdapat hubungan bermakna antara frekuensi penggunaan rokok elektrik dengan status kebersihan gigi dan mulut $(P=0,556)$. Hal ini sesuai dengan penelitian 
yang dilakukan oleh Holliday ${ }^{8}$ yang menyatakan bahwa dampak uap rokok elektrik terhadap rongga mulut lebih mengarah pada kerusakan jaringan lunak karena uap rokok elektrik tidak meninggalkan stain atau plak pada permukaan gigi. Hal ini didukung juga oleh penelitian Sherry et al. ${ }^{9}$ yang manyatakan bahwa efek samping dari uap rokok elektrik dalam rongga mulut yaitu mulut kering (xerostomia), iritasi tenggorokan/batuk kering, ulkus pada bagian palatal, mukosa bukal dan gingiva, serta inflamasi pada gingiva, sehingga dapat disimpulkan bahwa uap rokok elektrik lebih berdampak buruk pada jaringan lunak dan jaringan periodontal rongga mulut dibandingkan dampak uap rokok elektrik terhadap jaringan keras gigi.

\section{SIMPULAN}

Berdasarkan hasil penelitian ini dapat disimpulkan bahwa tidak terdapat hubungan bermakna antara penggunaan rokok elektrik dengan status kebersihan gigi dan mulut di komunitas Manado vapers.

\section{SARAN}

Bagi klinisi diharapkan dapat melakukan penyuluhan dan sosialisasi tentang kesehatan gigi dan mulut dan juga mengenai dampak penggunaan rokok elektrik terhadap rongga mulut pada pasien.

Disarankan untuk melakukan penelitian lanjut dengan cakupan yang lebih luas dan beragam mengenai hubungan rokok elektrik dan rongga mulut karena sangat kurangnya data yang tersedia mengenai dampak rokok elektrik secara spesifik terhadap rongga mulut khususnya di
Indonesia. Diharapkan hasil penelitian dapat diaplikasikan secara umum untuk pengembangan kesehatan gigi dan mulut.

\section{DAFTAR PUSTAKA}

1. Kusuma AR. Pengaruh merokok terhadap kesehatan gigi dan rongga mulut. Jurnal Majalah Ilmiah Sultan Agung. 2011; 49:4-8.

2. Riset Kesehatan Dasar (Riskesdas). Badan Penelitian dan Pengembangan Kesehatan Kementerian RI tahun 2013.

3. Damayanti A. Penggunaan rokok elektronik di komunitas personal vaporizer Surabaya. p. 250-61. [cited 2018 Feb 24] Available from: https://e-journal.unair. ac.id/JBE/article/download/2150/2465

4. Gayatri A, Susanto AD, Setiawati A. Nicotine replacement therapy. CDK189. 2012;39(1):25-9..

5. Tanuwihardja RK, Susanto AD. Rokok elektronik (electronic cigarette). Jurnal Respirologi Indonesia. 2012;32(1):5361.

6. Etter JF, Bullen C. A longitudinal study of electronic cigarette users. Addict Behav. 2014;39(2):491-4.

7. Dawkins L, Turner J, Roberts A, Soar K. 'Vaping' profile and preferences: an online survey of electronic cigarette users. Addiction. 2013;108(6):1115-25.

8. Holiday R. A dental perspective on electronic cigarettes: the good, the bad and the ugly. 2015. [cited 2018 Feb 24] Available from: https://www.oralhealth group.com/features/a-dentalperspective-on-electronic-cigarettesthe-good-the-bad-and-the-ugly/

9. Sherry JS, Blackstad NM, Wheatley KS. E cigarettes, vaping and chairside education. RHD. 2017;37(1):45-52. 